\title{
The sociodemographic profile of women participating in mammography screening in Lower Silesia
}

\author{
Elżbieta Garwacka-Czachor, Adam Maciejczyk, Marek Bębenek
}

\begin{abstract}
Introduction. Female breast cancer is the most common malignancy worldwide. An important element of cancer control involves population-based screening, which aims to reduce related mortality. Screening programs can only serve their purpose if they are long-term and available on a mass scale; accordingly, they are deemed effective as long as they cover at least $70 \%$ of the target population. Alarmingly, the coverage of breast cancer screening in Poland is markedly lower. The purpose of this study was to determine the impact of selected sociodemographic factors on the participation of women in mammography screening.

Material and methods. The study included a population of Lower Silesian women aged 50 to 69 , who participated in mammography screening, and analyzed a total of 32,626 questionnaires collected by means of a diagnostic survey between January 3, 2007 and December 30, 2011. Examined sociodemographic factors included the place of residence, age, educational level, and occupational status.

Results. The largest group of screening participants comprised women aged 55 to 59 (30\%), from Wrocław and the neighboring districts, with at least secondary education (74\%), mostly old-age and disability pensioners (55\%). Conclusions. Place of residence, age, education and occupation have a significant impact on the participation of Lower Silesian women in mammography screening. Age and disability pensioners aged 55-59 with at least secondary education are more likely to participate.
\end{abstract}

NOWOTWORY J Oncol 2017; 67, 2: 89-95

Key words: breast cancer, mammography screening, prevention

\section{Introduction}

Breast cancer is the most common malignancy worldwide, representing a major health issue and a growing social and economic burden for many developed countries [1-3]. A further systematic rise in its incidence in Europe, including Poland, may be expected in the coming future. The trend is directly linked to the ageing of the European population and its increased exposure to lifestyle risk factors $[4,5]$.

In 2012-2013, 1,671,149 new cases were diagnosed worldwide, including 494,077 in Europe, 17,142 in Poland, and 1,417 in Lower Silesia. Corresponding standardized incidence rates equaled, respectively: $43.1 ; 66.5 ; 51.8$, and 54.3 [6-8].

A key role in the struggle against breast cancer is played by secondary prevention, i.e. early detection and treatment of the disease. This is helped by population-based screening programs, whose overarching goal is to reduce related mortality rates. Detected early, breast cancer can be treated effectively with less radical methods, which directly translates into lower treatment costs. Early detection and treatment also reduce the risk of local relapse and distant metastasis, raising survival rates and improving the quality of life [9]. Accordingly, the resolutions and recommendations of the European Parliament have repeatedly reiterated the importance of screening as the most effective among the available tools of secondary prevention [10-13].

Adopted in 2005, the Act on Establishing the National Cancer Control Program for 2006-2015 laid the groundwork for the implementation of the Population-Based Early Breast Cancer Detection Program. The latter was elaborated in 
accordance with the guidelines set down in the Council Recommendation of 2 December 2003 on Cancer Screening [11] and provided free mammography to women in the 50-69 age group, which shows the highest incidence rate of breast cancer [14].

Screening programs can only serve their purpose if they are long-term and available on a mass scale; accordingly, they are deemed effective as long as they cover at least $70 \%$ of the target population. This threshold has not yet been reached in Poland. According to statistical data for the first half of 2013, the proportion of eligible women who participated in mammography screening was greater than $50 \%$ only in the West Pomeranian and the Lubusz Voivodeships. Everywhere else, it hovered between 37\% and 49\%; the relevant figure for Lower Silesia was 47\% [15]. Organizers and decision-makers alike are alarmed by the low participation rate.

The purpose of this study was to determine the impact of selected sociodemographic factors on the participation of Lower Silesian women in the mammography screening program at the Lower Silesian Oncology Center in Wrocław between 2007 and 2011.

\section{Material and methods}

In 2011, approximately 3 million people lived in Lower Silesia, more than half of them women $(1,513,602)$. In administrative terms, Lower Silesia comprises 26 counties and 3 towns with county rights. A total of 395,852 women were eligible for the Population-Based Early Breast Cancer Detection Program run by the Lower Silesian Oncology Center [16].

In the end, 32,626 women aged 50 to 69 took part in the program between 3 January 2007 and 30 December 2011. Data from 32,626 questionnaires were collected and analyzed in the Computer-Based Prevention Monitoring System [15]. Alongside questionnaires, the analysis also included information about the populace covered by mammography screening, introduced into the system by the Lower Silesian Voivodeship Coordinating Center for the Early Breat Cancer Detection Program, as well as statistical data obtained from the Central Statistical Office (GUS).

Studies conducted in various countries have shown that health behaviors depend on a number of social and demographic factors, such as age, education, marital status, family situation, social class, and material conditions [17-21]. This article focuses specifically on the age, education, occupational status, and place of residence of screening participants under study. Women aged 50 to 69 were grouped into 5-year age brackets. Their level of education was described on a scale ranging from incomplete primary to a university degree. Occupational status was defined as the current occupation and the place of residence was listed as the nearest county.
Table I. Women who participated in the Population-Based Early Breast Cancer Detection Program at the Lower Silesian Oncology Center between 2007 and 2011

\begin{tabular}{lc}
\hline Year & Number of women \\
\hline 2007 & 6,237 \\
2008 & 5,558 \\
2009 & 6,326 \\
2010 & 6,788 \\
2011 & 7,717 \\
Total & 32,626 \\
\hline
\end{tabular}

Source: Computer-based Prevention Monitoring System

\section{Statistical analysis}

Study groups and variables were summarized by means of descriptive statistics, including the mean, standard deviation, confidence intervals, and percentage distributions. Measurable variables were tested for normality with the Shapiro-Wilk test and the Fisher test was used to assess the statistical significance of differences in the distribution of discrete variables. Changes that occurred in the successive years of the screening program were presented as trends and regressions. The impact of age and education on the willingness to participate the screening program was assessed by the homogeneity of variance test, followed by the ANOVA single-factor analysis. The threshold of statistical significance was defined as $p \leq 0.05$. All calculations were performed in Statistica 10 and Microsoft Excel.

\section{Results}

The number of women who participated in the program in successive years is shown in Table I. A slight but systematic increase in participation can be observed beginning in 2009.

\section{Sociodemographic factors}

Place of residence

As shown in Table II, patients from Wrocław (77.9\%) and the neighboring counties (Wrocław, Oława, Trzebnica, Strzelin, Środa Śląska, and Wołów) accounted for $91.9 \%$ of all women who took part in mammography screening at the Lower Silesian Oncology Center.

Age

The largest group ( $n=9,889 ; 30 \%$ ) comprised women aged 55 to 59 . Respondents between the ages of 50 and 54 represented $29 \%$ of the screening group, while the proportion of participants in the 65-69 age bracket was the lowest ( $n=5,023 ; 16 \%$ ). Figure 1 shows the distribution of the number of women who took part in the Population-Based Early Breast Cancer Detection Program in 2009-2011 as a factor of age and testing year, along with relevant trend lines. 
Table II. Number and percentage of eligible women who participated in the mammography screening by county

\begin{tabular}{|c|c|c|c|c|}
\hline \multirow[t]{2}{*}{ County, town } & \multicolumn{2}{|c|}{ Number of women, $L_{k}$} & \multicolumn{2}{|c|}{ Percentage of women, \% } \\
\hline & Participating & Eligible & Participating & Eligible \\
\hline City of Wrocław & 25,201 & 92,051 & 77.9 & 23.3 \\
\hline Wrocław county & 1,549 & 12,600 & 4.8 & 3.2 \\
\hline Oława county & 802 & 9,671 & 2.5 & 2.4 \\
\hline Trzebnica county & 701 & 9,568 & 2.2 & 2.4 \\
\hline Strzelin county & 617 & 5,465 & 1.9 & 1.4 \\
\hline Środa Śląska county & 425 & 5,815 & 1.3 & 1.5 \\
\hline Wołów county & 419 & 6,011 & 1.3 & 1.5 \\
\hline Total: City of Wrocław + neighboring counties & 29,714 & 141,181 & 91.8 & 35.7 \\
\hline Other counties, including: & 2,648 & 254,671 & 8.2 & 64.3 \\
\hline Świdnica county & 377 & 22,112 & 1.2 & 5.6 \\
\hline Dzierżoniów county & 311 & 14,587 & 1.0 & 3.7 \\
\hline Ząbkowice country & 308 & 9,121 & 1.0 & 2.3 \\
\hline Kłodzko county & 226 & 23,632 & 0.7 & 6.0 \\
\hline Oleśnica county & 197 & 12,995 & 0.6 & 3.3 \\
\hline Polkowice county & 168 & 7,233 & 0.5 & 1.8 \\
\hline Jawor county & 139 & 6,664 & 0.4 & 1.7 \\
\hline Głogów county & 102 & 12,695 & 0.3 & 3.2 \\
\hline Lubin county & 99 & 15,532 & 0.3 & 3.9 \\
\hline Milicz county & 98 & 4,540 & 0.3 & 1.1 \\
\hline Bolesławiec county & 94 & 11,621 & 0.3 & 2.9 \\
\hline Legnica county & 65 & 6,739 & 0.2 & 1.7 \\
\hline City of Wałbrzych & 63 & 10,000 & 0.2 & 2.5 \\
\hline Lubań county & 58 & 7,688 & 0.2 & 1.9 \\
\hline City of Legnica & 58 & 15,413 & 0.2 & 3.9 \\
\hline Zgorzelec county & 56 & 12,654 & 0.2 & 3.2 \\
\hline Kamienna Góra county & 45 & 6,056 & 0.1 & 1.5 \\
\hline Złotoryja county & 44 & 5,749 & 0.1 & 1.5 \\
\hline Wałbrzych county & 36 & 16,775 & 0.1 & 4.2 \\
\hline Góra county & 34 & 4,180 & 0.1 & 1.1 \\
\hline Jelenia Góra county & 25 & 8,958 & 0.1 & 2.3 \\
\hline Lwówek Śląski county & 23 & 6,211 & 0.1 & 1.6 \\
\hline City of Jelenia Góra & 22 & 13,516 & 0.1 & 3.4 \\
\hline Lower Silesian Voivodeship & 32,362 & 395,852 & 100 & 100 \\
\hline
\end{tabular}

Source: table created by the author based on data from the Central Statistical Office and the Computer-Based Prevention Monitoring system

During the first three years (2007-2009), an inverse relationship could be observed between women's age and their willingness to participate in the program. In the fourth and fifth year (2010 and 2011), the majority of participants were aged 56 to 62 . The proportion of respondents over the age of 65 was low throughout (Fig. 1).

Figure 2 shows the number of women who entered the screening program as a percentage of the total eligible population. In successive years (2007-2011), only slight changes were observed in these figures and their scope remained within one standard deviation from the mean.
However, in 2010 and 2011, a proportionally higher number of older than younger women participated in the screening.

\section{Occupational status}

Old-age and disability pensioners represented the largest group among screening participants ( $n=17,929 ; 55 \%)$, followed by white-collar workers ( $n=7,865 ; 24.1 \%)$ and blue-collar workers ( $n=2,477 ; 7.6 \%)$. The smallest group comprised women who ran their own agricultural farms.

The percentage of pensioners continued to increase until the age of 60-64 and then diminished. For other 


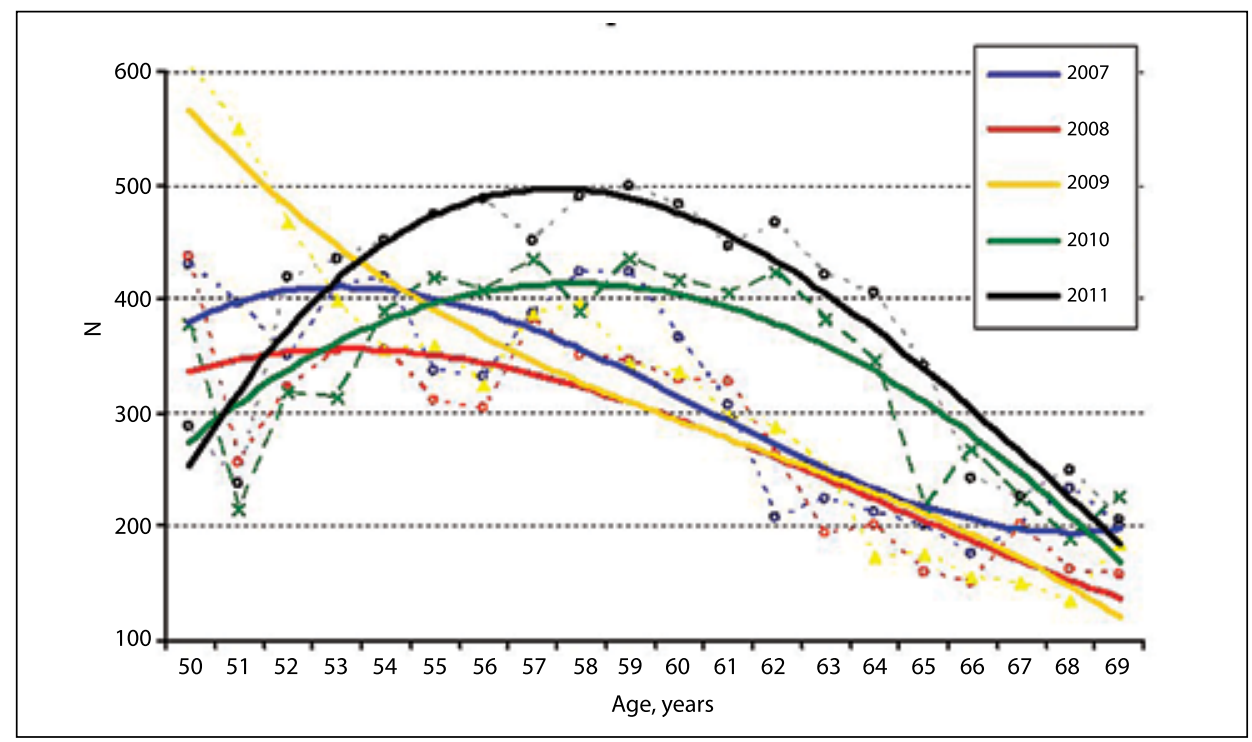

Figure 1. Distribution of Lower Silesian women participating in the Program as a function of age and testing year

occupational groups, participation systematically decreased with age (Fig. 3).

\section{Education}

Most respondents reported having completed secondary $(n=14,623 ; 45 \%)$ or higher education $(n=7,528 ; 23 \%)$. Women who attended some college accounted for $6 \%$ ( $n=1,954$ ) of all screening participants, and the corresponding figures for those who graduated from a vocational or primary school were $15 \%(n=4,744)$ and $7 \%(n=2,407)$, respectively. Respondents with primary and incomplete primary education were significantly older than those who completed at least vocational training (Fig. 4, Tab. III).

No statistically significant correlation was shown to exist between the age and the educational level of women who participated in the screening program. Younger patients (in the 50-54 and 55-59 age bracket), however, were slightly more likely to have completed secondary or higher education (Fig.5).

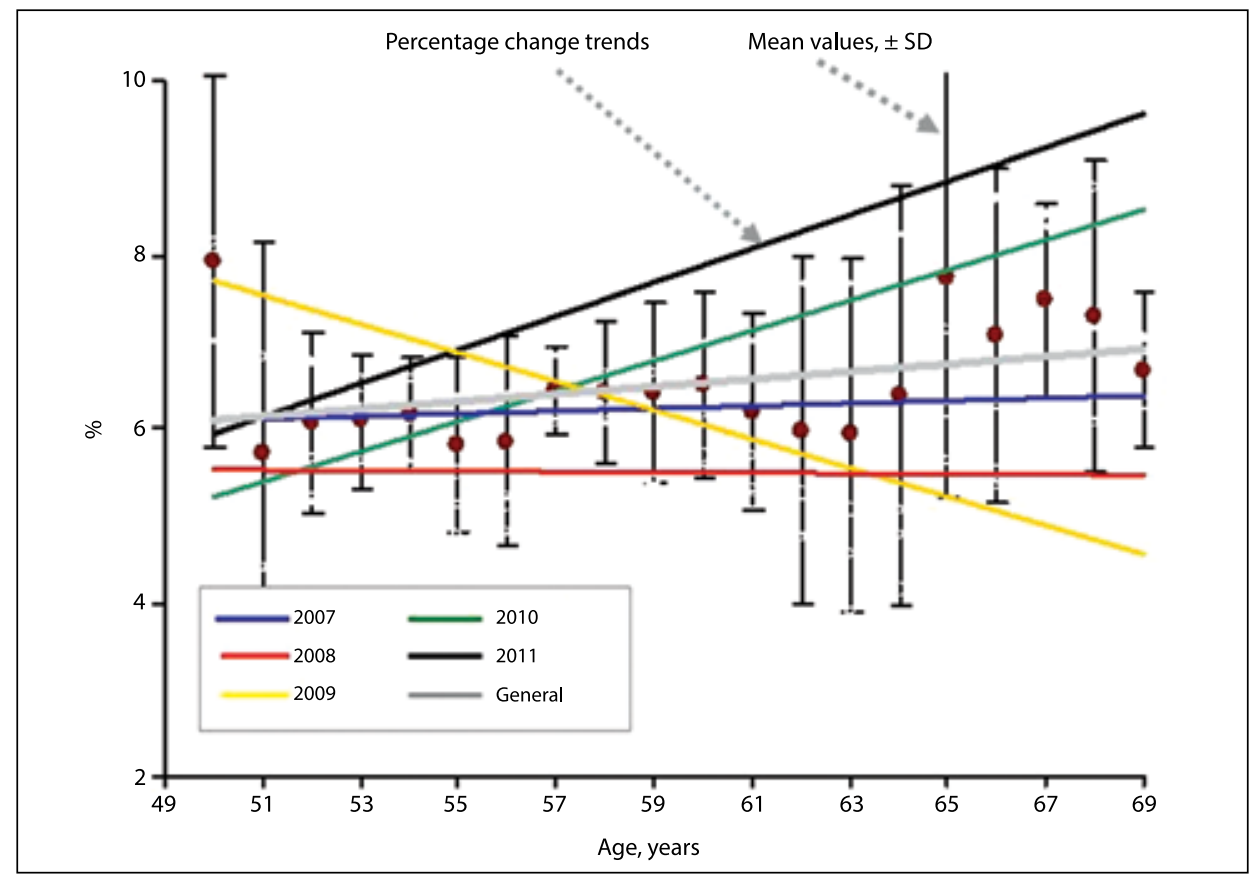

Figure 2. Proportion of women who participated in the screening program relative to the total eligible population in successive years 


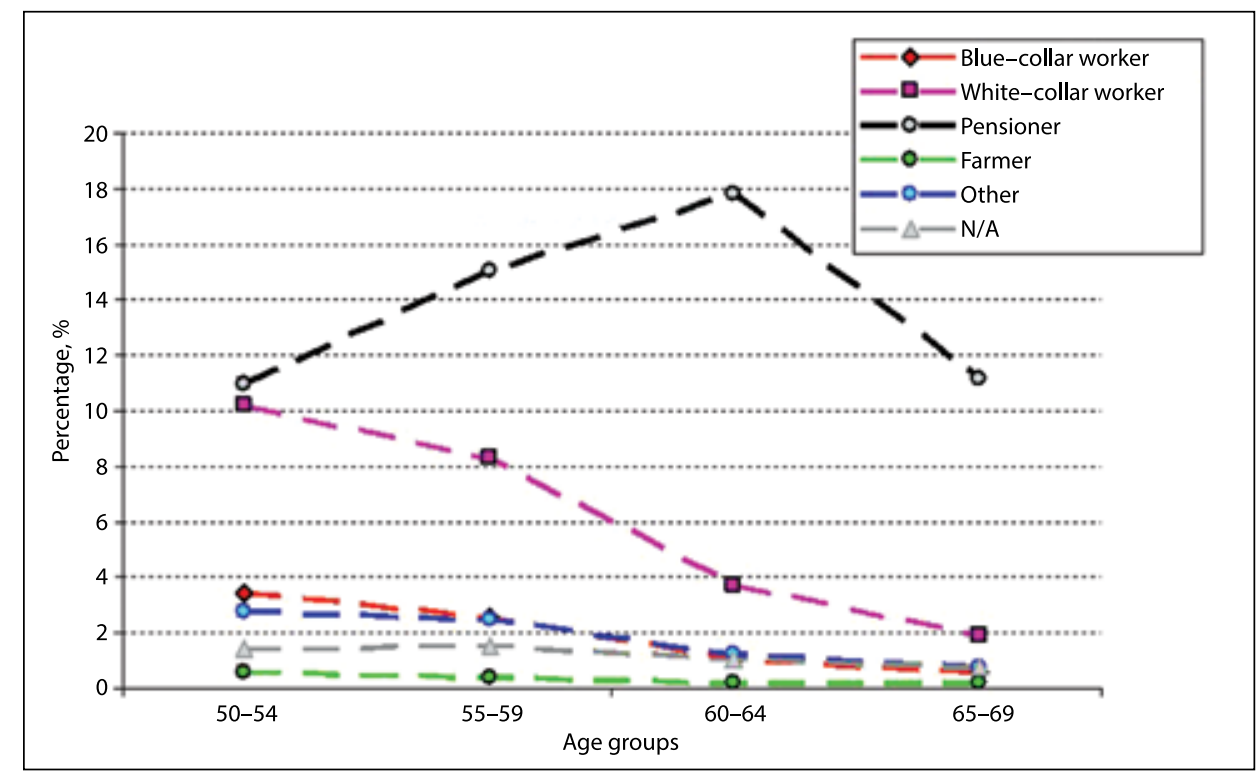

Figure 3. Occupational structure of women who participated in the screening by 5 -year age brackets

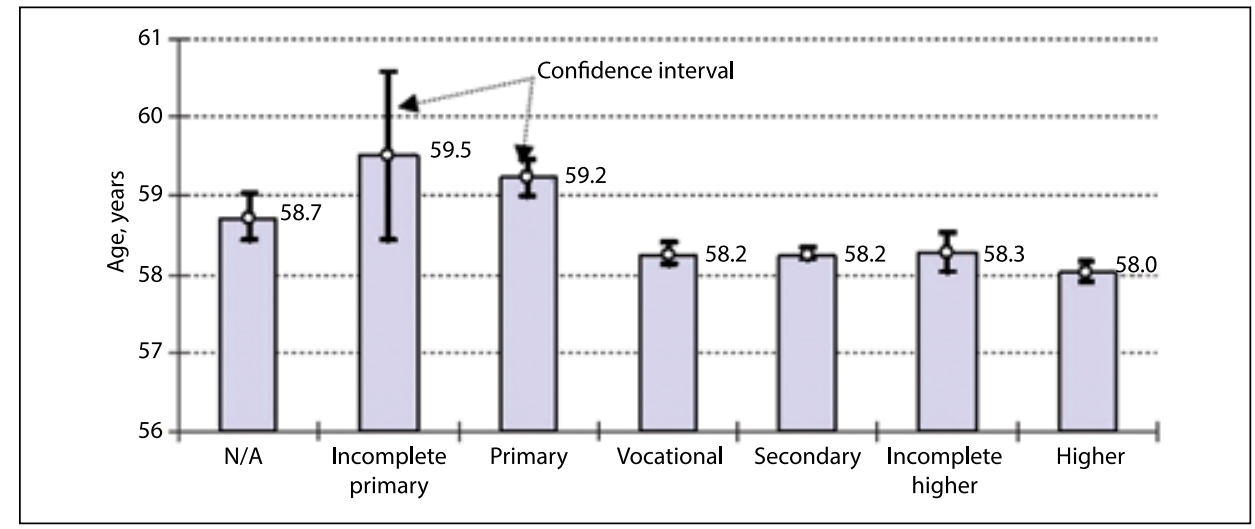

Figure 4. Relationship between the educational level and the mean age of screening participants

\section{Discussion}

Breast cancer is the leading cause of premature death among women, second in importance only to cardiovascular diseases. For this reason, it is particularly essential to identify the sociodemographic factors that affect the level of participation in mammography screening programs.

In the current study, participation was significantly higher among younger women (59\% of all tests were performed in the 50-59 age bracket) who had completed secondary or higher education (74\%) and lived in Wrocław (78\%). Willingness to participate increased as a function of educational level, which reflects the greater awareness of health risks and lifestyle choices among better educated respondents. These data are consistent with the findings of another study, conducted in 2011 in Greater Poland, which reported much higher mammography participation levels among women from large cities (in this case: Poznań), aged 55-59, with secondary or higher education [22]. Results of earlier studies also suggest similar differences in the sociodemographic profile of those who enter secondary prevention programs. It has been shown that they are more likely to be younger and better educated [23-25].

The largest group in the current study comprised pensioners (55\%), followed by white-collar workers (24.1\%); women working on agricultural farms represented only $1.3 \%$. The high proportion of pensioners among women aged 50-69 who participated in the program may be accounted for in several ways. Firstly, because of the nature of Polish law, many could have acquired pension rights at a lower age. Secondly, as they are mostly out of work, pensioners have more free time to devote to prevention programs. The study also showed that more than three 
Table III. Statistical significance of the differences in the age of participants with different educational levels

\begin{tabular}{|c|c|c|c|c|c|c|}
\hline \multirow[t]{2}{*}{ Education } & \multicolumn{6}{|c|}{ Mean age, $p$ value } \\
\hline & 59.50 & 59.21 & 58.24 & 58.24 & 58.27 & 58.01 \\
\hline Incomplete primary & & 0.577 & 0.014 & 0.013 & 0.018 & 0.003 \\
\hline Primary & 0.577 & & 0.000 & 0.000 & 0.00 & 0.000 \\
\hline Vocational & 0.014 & 0.000 & & 0.998 & 0.862 & 0.019 \\
\hline Secondary & 0.014 & 0.000 & 0.998 & & 0.844 & 0.002 \\
\hline Incomplete higher & 0.018 & 0.000 & 0.861 & 0.844 & & 0.058 \\
\hline Higher & 0.003 & 0.000 & 0.019 & 0.002 & 0.058 & \\
\hline
\end{tabular}

quarters (78\%) of all participants lived in Wrocław, probably because large urban centers tend to provide better access to healthcare resources. This observation is consistent with the findings of many previous studies conducted both in Poland and abroad [17-21].

According to statistical data for 2002 , the highest premature mortality is observed among women with the lowest levels of education [26]. This was confirmed by the findings of the current study, which showed that women with vocational, primary, and incomplete primary education were significantly less likely to participate in mammography screening. Results of earlier surveys similarly confirm that these groups have a lower awareness of cancer, are less likely to take care of their health, more often distrust treatment methods, and tend to doubt the effectiveness of preventive measures [27, 28]. In 2010, an opinion poll about the importance of breast cancer prevention was conducted among women in the villages of the Kuyavian-Pomeranian Voivodeship [29]. More than half had never taken a screening test. Most admitted that their knowledge about the role of mammography, the presence of alarming symptoms, or medical recommendations were not a sufficient motivating factor. The only thing that could make them sign up for mammography was the discovery of a lump in the breast.

Such an avoidance strategy means that many women undergo screening tests too late in the day, and if breast cancer is diagnosed, this leads to more aggressive treatment and a significantly worse prognosis. In order to encourage better pro-health behaviors among Polish woman, it is essential to raise their awareness of the role of prevention, impart indispensable knowledge in accessible form, and ensure the motivation and support of local healthcare providers and communities.

\section{Conclusions}

1. The place of residence, age, educational level, and occupational status have a significant impact on the willingness of Lower Silesian women to participate in mammography screening.

2. The largest group of participants comprised women from Wrocław and the neighboring counties, aged 55 to $59(30 \%)$, most of whom were pensioners (55\%) and had completed at least secondary education (74\%).

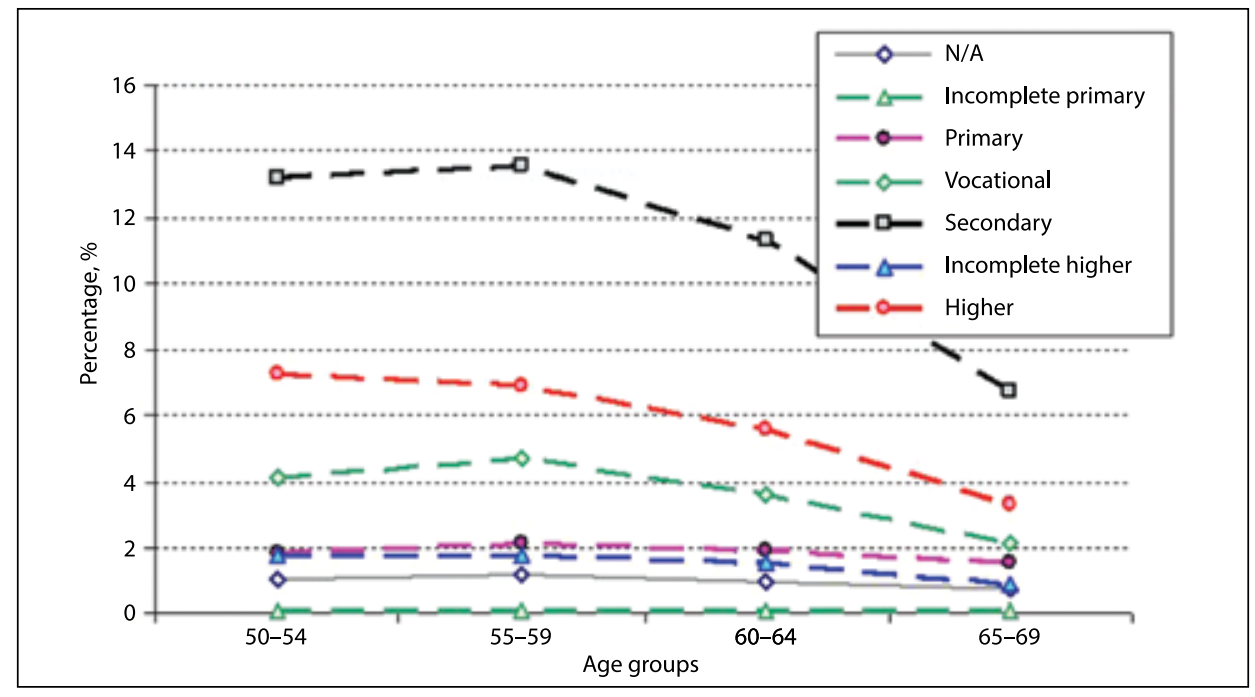

Figure 5. Educational level of screening participants by 5-year age brackets 
3. The slight but systematic increase in participation in the screening program run by the Lower Silesian Oncology Center in Wrocław is still unsatisfactory, especially in the group of women living outside large urban agglomerations.

\section{Conflict of interest: none declared}

\author{
Elżbieta Garwacka-Czachor, MD, PhD \\ Lower Silesian Oncology Center in Wrocław \\ Pl. Hirszfelda 12 \\ 53-413 Wrocław, Poland \\ e-mail:garwacka.e@dco.com.pl
}

Received: 11 Jul 2016

Accepted: 19 Jan 2017

\section{References}

1. US Preventive Services Task Force. Screening for breast cancer: U.S. Preventive Services Task Force recommendation statement. Ann Intern Med 2009; 151: 716-726.

2. Szewczyk K. Epidemiologia i profilaktyka raka piersi. In: Kornafel J (red.). Rak piersi. Warszawa: CMKP, 2011

3. Ferlay J, Autier $\mathrm{P}$, Boniol $\mathrm{M}$ et al. Estimates of the cancer incidence and mortality in Europe in 2006. Ann Oncol 2007; 18: 581-592.

4. Commission of the European Communities. Report from the Commission to the Council, the European Parliament, the European Economic and Social Committee and the Committee of the Regions. Implementation of the Council Recommendation of 2 December 2003 on cancer screening (2003/878/EC). COM (2008) 882 final, Brussels, 22.12.2008.

5. Didkowska J. Epidemiologia nowotworów złośliwych w Polsce. In: Meder J (ed.). Podstawy onkologii klinicznej. Warszawa: CMKP, 2011.

6. International Agency for Research on Cancer. GLOBOCAN 2012. http:// globocan.iarc.fr/Pages/summary_table_site_sel.aspx [30.12.2016].

7. Wojciechowska U, Didkowska J. Zachorowania i zgony na nowotwory złośliwe w Polsce. Warszawa: Centrum Onkologii — Instytut im. Marii Skłodowskiej-Curie, Krajowy Rejestr Nowotworów. http://onkologia. org.pl/raporty [30.12.2016].

8. Błaszczyk J, Jagas M, Hudziec P. Nowotworyzłośliwe w woj. dolnoślaskim w roku 2013. Wrocław: Dolnośląskie Centrum Onkologii, 2015.

9. Tkaczuk-Włach J, Sobstyl M, Jakiel G. Rak piersi — znaczenie profilaktyki pierwotnej i wtórnej. Przegl Menopauz 2012; 11: 343-347.

10. The Council of the European Union. Council recommendation of 2 December 2003 on cancer screening. Official Journal of the European Union. L 327/34 [16.12.2003]

11. European Parliament. European Parliament resolution of 05 June 2003 on breast cancer in the European Union. (P5 TA(2003)0270): OJ C $68 \mathrm{E}$, 18.3.2004: 611
12. European Parliament. European Parliament resolution of 25 October 2006 on breast cancer in the enlarged European Union. (P6_TA(2006)0449 B60528/2006): OJ C 313 E, 20.12.2006: 273.

13. The European Parliment. European Parliament resolution of 6 May 2010 on the Commission communication on Action Against Cancer: European Partnership (2009/2103(INI)) (2011/C 81 E/19). Official Journal of the European Union C $81 \mathrm{E} / 95,15.3 .2011$.

14. Narodowy Fundusz Zdrowia. Zarzadzenie Nr 86/2005 z dnia 13 października 2005 r. Prezesa Narodowego Funduszu Zdrowia w sprawie zatwierdzenia do realizacji profilaktycznych programów zdrowotnych.

15. Dolnośląski Wojewódzki Ośrodek Koordynujący Program Profilaktyki Raka Piersi. Dolnoślaskie Centrum Onkologii we Wrocławiu. System Informatyczny Monitorowania Profilaktyki (SIMP) [01.07.2013].

16. GUS. Stan zdrowia ludności Polski w 2009 r. Available at http://www. stat.gov.pl/cps/rde/xbcr/gus/ZO stan_zdrowia_2009.pdf [21.01.2016].

17. Ostrowska A. Profilaktyka raka szyjkimacicy iraka piersi:Wiedza, postawy izachowania kobiet. Wybrane wyniki badań. Warszawa: Instytut Filozofii i Socjologii PAN, 2010.

18. Padoan M, Ferrante D, Pretti G et al. Study of socio-economic characteristics, diagnosis and outcome of women participating or not participating in mammogram screening. Ann lg 2014; 26: 518-526.

19. Madadi $M$, Zhang S, Yeary KH et al. Analyzing factors associated with women's attitudes and behaviors toward screening mammography using design-based logistic regression. Breast Cancer Res Treat 2014; 144: 193-204.

20. Martín-López R, Jiménez-García R, Lopez-de-Andres A et al. Inequalities in uptake of breast cancer screening in Spain: analysis of a cross-sectional national survey. Public Health 2013; 127: 822-827.

21. Dundar PE, Ozyurt BC, Erdurak K. Sociodemographic determinants of nonattendance in a population-based mammography screening program in the city of Manisa, Turkey. Sci World J 2012; 2012: 816903.

22. Dyzmann-Sroka A, Bagniewska K, Chyła K et al. Dlaczego Wielkopolanki nie robią badań mammograficznych? Raport. Zeszyty Naukowe WCO 2012; 9: 169-181.

23. Nowicki A, Miłecka A. Wyniki badań profilaktycznych w kierunku raka piersi realizowanych w latach 2004-2005 w powiecie sierpeckim. Współcz Onkol 2007; 11: 437-443.

24. Nowicki A, Stogowska I. Wczesne wyniki badania profilaktycznego wykrywania raka piersi. Ginekol Pol 2007; 78: 464-470.

25. Wojcierowska A, Renn-Żurek A, Dziedziczak-Buczyńska M et al. Programy profilaktyczne dla kobiet realizowane na terenie województwa łódzkiego. Probl Hig Epidemiol 2010; 91: 511-516.

26. Rada Ministrów RP. Załącznik do Uchwały Nr 90/2007 Rady Ministrów, Narodowy Program Zdrowia na lata 2007-2015 z dnia 15 maja 2007 r.

27. Chojnacka-Szawłowska G. Zachowania zdrowotne w profilaktyce onkologicznej. Psychoonkologia 2003; 7 (1).

28. Marcinkowska M, Mazurkiewicz P, Kozaka J et al. Przyczyny niskiej frekwencji kobiet w profilaktycznych badaniach mammograficznych. Psychoonkologia 2006; 10 (2).

29. Koper A, Kalisz Z, Mierzwa T et al. Znaczenie profilaktyki raka piersi w opinii kobiet wiejskich w woj. kujawsko-pomorskim. Probl Hig Epidemiol 2010; 91 (Supl. 1): 54-55 